\title{
Economic feasibility of abscisic acid application to uniform 'Rubi' grapes coloration
}

\author{
Francisco José Domingues Neto ${ }^{*}$, Katia Nachiluk², Priscilla Rocha Silva Fagundes², Marco Antonio \\ Tecchio $^{1}$
}

\author{
${ }^{1}$ São Paulo State University (UNESP), School of Agriculture, Botucatu, José Barbosa de Barros Street, 18.610- \\ 307, Botucatu, São Paulo, Brazil \\ ${ }^{2}$ Institute of Agricultural Economics (IEA), Paulista Agribusiness Agency of the Secretariat of Agriculture and \\ Supply of the State of São Paulo, Brazil
}

\author{
*Corresponding author: fjdominguesneto@hotmail.com
}

\begin{abstract}
São Miguel Arcanjo municipality (23 31 'S, 47 35' $\mathrm{O}$ and average altitude of $660 \mathrm{~m}$ ) is part of one of the three main grape productive regions of São Paulo state, Brazil. The 'Rubi' grapes (Vitis vinifera) production constraint in that region is to achieve the variety characteristic coloration, which affects commercialization. The color of the berry grapes is due to the existence of anthocyanins and their accumulation seems to be at least in part regulated by abscisic acid. Therefore, exogenous applications of this regulator may increase the anthocyanins concentration in the grapes' skin. The aim of this paper is to evaluate the economic feasibility of abscisic acid application for treatment of the 'Rubi' grapes color uniformization and the impact of this application in the production cost. Production costs were calculated for the abscisic acid treated grapes and the non-treated grapes for a 'Rubi' grapes variety in the sixth year of production and recommended abscisic acid concentration for the region (400 mg L-1 at the beginning of the maturation $+200 \mathrm{mg} \mathrm{L}^{-1}$ at 25 days after first application). The abscisic acid was applied on the berry bunches in the morning using a backpack sprayer that provided full and uniform coverage. Economic feasibility was determined by the increment in the sale price of the final product due to the berries' quality achieved with the treatment. The cost components measured were: production cost, variable and fixed cost quota, effective operational cost, total operational cost, operational profit and profitability index. Technical coefficients input prices, machinery and implements compose the production cost and were surveyed at the property where the experiment was performed. The cost structure is the Total Operating Cost to which social charges, machinery depreciation, interest rate and depreciation of a onehectare area with a lifespan of 20 years were added. Prices paid to producers in the same period were collected from CEAGESP database for the profitability analysis. The Total Operating Cost for grape's production with abscisic acid treatment was $26.12 \%$ superior to the one of the grapes produced without the treatment, thus adding a US\$ 0.15 increment in the paid price per kilogram of the final product. Therefore, this experiment has shown that abscisic acid application is a profitable investment that adds value to the final product cultivated in low thermal amplitude regions where the grapes cannot achieve the variety's characteristic coloration.
\end{abstract}

Keywords: Vitis vinifera; abscisic acid; anthocyanins; Total Operating Cost; cost-effectiveness

Introduction

Cultivated in both tropical and temperate climates, grapes are socioeconomically important for most countries. They are one of the main fruits produced around the world and a relevant share of the international fruit's market for the last decades. China was the leading producer of grapes in 2017, responsible for $15.1 \%$ of the total production, whereas Brazilian production was $2.2 \%$ of total production, placing the country in the $12^{\circ}$ position in the world ranking. Regarding area, Brazil is in $22^{\circ}$ position but due to production technologies investment the country has a prominent productivity that places it in second position in the world ranking (Food and Agriculture Organization of the United Nations, 2019).

Brazilian viticulture has regional characteristics according to the destination of the production. Rio Grande do Sul state is the main grape producing region, its viticulture park produces the juice and wine production varieties. Next are Pernambuco state, whose park produces both fine table grapes and industry-destined grapes, and São Paulo state, whose production is mostly grapes for in natura consumption (Instituto Brasileiro de Geografia e Estatística, 2018).

São Paulo state is the largest table grape producer in Brazil. Production is concentrated in three main regions: Campinas', Jales' and Itapetininga's Rural Development Offices - RDOs. São Miguel Arcanjo municipality is located in the Itapetininga RDO, where viticulture is the main economic activity of small family farms (Fagundes et al., 2008) having an important socioeconomic role. Rustic grape production has increased in the state over the last decade, as it is less labor-intensive, 
production cost is lower and profitability is larger than the fine table grape. According the agricultural census by the Secretaria de Agricultura e Abastecimento (2019) $66.2 \%$ of the state's Units of Agricultural Production (UAPs) that produce grapes are rustic variety producers and 'Niagara rosada' is the main produced variety. Fine table grape is about $33.5 \%$ of fine grape's planting and only $0.3 \%$ of the UAPs plant the industrydestined varieties. In Campinas RDO, $51.41 \%$ of the UAPs produce rustic grapes; on the other hand, in Itapetininga (44.6 $\%)$ and Jales (21.55\%) regions, the fine grape production prevails (Secretaria de Agricultura e Abastecimento, 2019). Regarding profitability to the producer, it is worth pointing out that the fine table grape is one of the most profitable alternatives to small family producers if it presents the variety characteristic attributes, such as bunch shape, sweetness, and coloration. Regions of low thermal amplitude can negatively impact the coloration of colored grapes' varieties, such as the 'Rubi' variety. The characteristic color of this variety is one of the most important attributes that defines the grape's commercial price and competitiveness. Grape's daily price variation at CEAGESP trading post can achieve up to $200 \%$ because of the quality attributes such as coloration (Almeida, 2003). Fine grape's valuation varies with factors such as high sugar content, bagasse's color and turgidity, bunch and berry sizes, package, coloration (for colored grapes) and brand or producer's name. Therefore, cultural traits that may generate product valuation increase producer's profitability. Capello et al. (2017) studied particularities and specificities of the 'Niagara' grapes production in the main regions of the State of São Paulo. The study evaluated copper products and total production costs highlighting the importance of measuring production costs in this business. Economic feasibility analysis is the identification of the factors that directly impact the company's market potential, resource constraints and production processes (Kebede, Radae fa, 2017). It is one of the tools to assess the production viability, the usage of differentiated products and the added value at the time of commercialization. This paper aimed to evaluate the economic feasibility of abscisic acid in coloration uniformity, synthesis, and anthocyanins accumulation in the 'Rubi' grape and the impacts in production cost.

\section{Results and discussion}

\section{Total operational cost}

The Total Operational Cost (TOC) to produce grapes without treatment was US\$10,054.21 and the cost per kilogram ( $\mathrm{kg}$ ) was US\$ 0.34 (Table 1) in the group of costs analyzed. The TOC to produce grapes with abscisic acid treatment was US\$ $12,680.22$ and the cost per kilogram of the fruit was US\$ 0.42 (Table 2), i. e., the TOC was $26.12 \%$ higher than the cost of production of grapes without treatment for a productivity of $30 \mathrm{t} \mathrm{ha}^{-1}$. The treatment does not induce greater productivity but a better coloration uniformity in the grapes, thus improving price quotation of grape's commercialization.
Additionally, an increase of US\$ 0.15 in the price paid per grape kilogram was verified, which represents $16.66 \%$ of the commercial value.

\section{Effective operational cost}

Regarding the TOC value of the grapes with and without treatment, consumables (fungicide, insecticide, fertilizer, and regulators) represented the greater cost in the EOC, $27.0 \%$ and $34.8 \%$ respectively, followed by labor costs (Figures 1 and 2 ). Fungicide was the most used consumable in number of applications due to the culture needs and represented $12.00 \%$ (without treatment) and $9.51 \%$ (with treatment) of the EOC. The 'Rubi' grape is essentially a table product requiring a large number of manual treatments and fungicide applications, thus the high-cost percentages with consumables and labor. The treatment with abscisic acid represented $13.42 \%$ increase in the value spent with consumables, including the surfactant; regarding the TOC, a $26.12 \%$ increase was verified. Regular labor charges were the second greatest cost forming the TOC of the grapes' production with and without treatment production, representing $21.3 \%$ and $22.6 \%$, respectively. Although the 'Rubi' grape is a variety of fine table grapes that require most of the manual treatments applicable to the culture, the item machinery operation was the third greatest cost, representing $20.5 \%$ of the TOC without treatment and $16.3 \%$ with treatment. This was the result of two factors: a large number of applications of fungicides by a tractor coupled to a sprayer and the use of the tractor for input and postharvesting transportations. A large number of spraying with fungicides is due to the variety sensitivity to fungal diseases, such as mildew and powdery mildew (Inglez de Sousa, 1996).

The increase in the production cost of the grapes with abscisic acid application was $26.1 \%$. However, the application provided a significant increase in fruit coloration, altering the product standards and commercial value, for it boosted synthesis and accumulation of anthocyanin, the pigments that color the fruits (Ribichaud, Noble, 1990).

\section{Indicators' profitability}

The indicators' profitability results (Table 3 ) indicate that the grapes that received the treatment had an increase of $16.67 \%$ in gross profit in relation to the product without treatment.

The amount of grapes necessary to pay for the production costs, with the objective of achieving the breakeven point, is $10,928 \mathrm{~kg}$ for the TOC of the production of grapes without treatment and $11,851 \mathrm{~kg}$ for the grapes with treatment (Table 3 ). The operational profit of the production system with treatment presented a variation superior to $11.25 \%$ and a profitability index of $4.87 \%$ in the production with the application abscisic acid, meaning that the available revenue tax is viable after the payment of the operational costs. To conclude this cost analysis, the variation between systems was $11.98 \%$. 
Table 1. Cost components for the production of 'Rubi' grapes in pergola system, without abscisic acid treatment, São Miguel Arcanjo municipality, São Paulo state, Brazil, 2016.

\begin{tabular}{llllll}
\hline ITEM & COE & $\%$ & COT & $\%$ & US\$ (kg) \\
\hline Labor & $2,270.81$ & 32.2 & $2,270.81$ & 22.6 & 0.08 \\
Machinery operation & $2,061.40$ & 29.3 & $2,061.40$ & 20.5 & 0.07 \\
Consumables & $2,711.44$ & 38.5 & $2,711.44$ & 27.0 & 0.09 \\
EFFECTIVE OPERATIONAL COST $^{\text {Financial charges }}{ }^{1}$ & $7,043.65$ & 100.0 & $7,043.65$ & & \\
Direct social charges $^{2}$ & & & 41.09 & 0.4 & 0.01 \\
Grapevine depreciation/ha $^{3}$ & & & 131.47 & 1.3 & 0.01 \\
Machinery and equipment depreciation $^{\text {CSSR }}$ & & & $1,732.93$ & 17.2 & 0.02 \\
TOTAL OPERATIONAL COST $^{4}$ & & & 469.93 & 4.7 & 0.03 \\
\end{tabular}

${ }^{1}$ Interest of $3.5 \%$ p. a. over $50 \%$ of EOC during the production cycle. ${ }^{2}$ Charges over regular labor and tractor operator salaries (33 \%). ${ }^{3}$ Refers to the Total Operational Cost (TOC) of the formation, distributed throughout the grapevine lifespan (20 harvests).

${ }^{4}$ Rural Social Security Contribution ( $2.3 \%$ over the gross revenue).

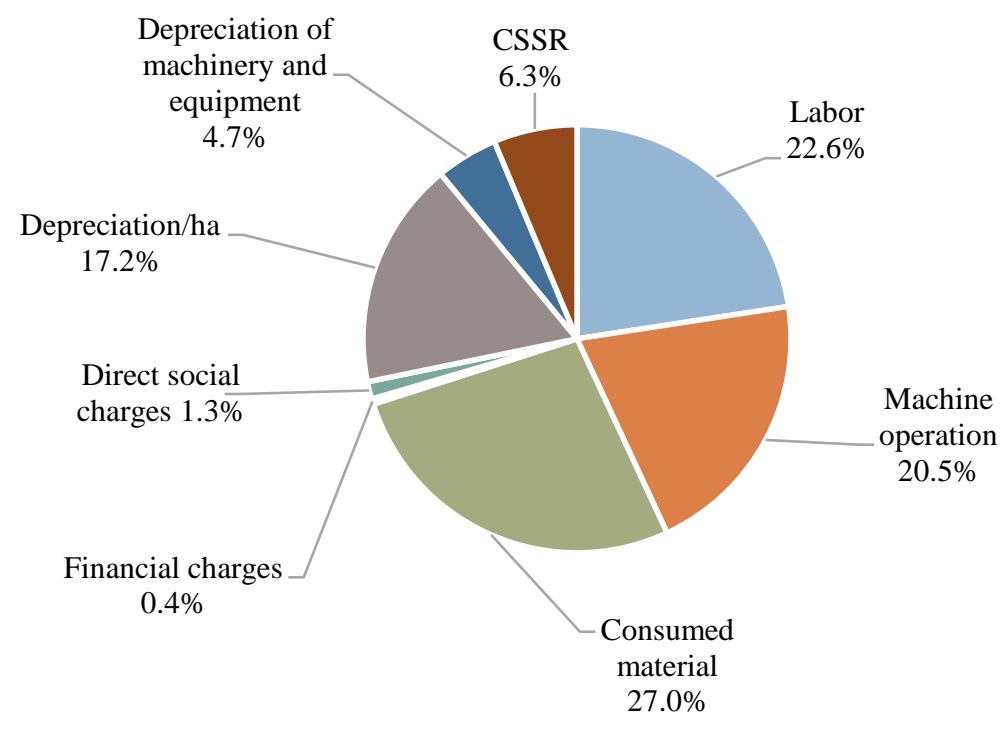

Figure 1. Percentual participation of the items forming the Total Operational Cost (TOC) in the 'Rubi' grape without abscisic acid treatment production, São Miguel Arcanjo municipality, São Paulo state, Brazil, 2016.

Table 2. Cost components for the production of 'Rubi' grapes in pergola system, with abscisic acid treatment, São Miguel Arcanjo municipality, São Paulo state, Brazil, 2016.

\begin{tabular}{|c|c|c|c|c|c|}
\hline ITEM & COE & $\%$ & COT & $\%$ & US\$ kg \\
\hline Labor & $2,701.75$ & 29.4 & $2,701.75$ & 21.3 & 0.09 \\
\hline Machinery operation & $2,068.10$ & 22.5 & $2,068.10$ & 16.3 & 0.07 \\
\hline Consumables & $4,412.61$ & 48.1 & $4,412.61$ & 34.8 & 0.15 \\
\hline EFFECTIVE OPERATIONAL COST & $9.182,47$ & 100.0 & $9.182,47$ & & \\
\hline Financial charges ${ }^{1}$ & & & 53.56 & 0.4 & 0.001 \\
\hline Direct social charges ${ }^{2}$ & & & 156.42 & 1.2 & 0.01 \\
\hline Grapevine depreciation $/ \mathrm{ha}^{3}$ & & & $2,070.00$ & 16.3 & 0.07 \\
\hline Machinery and equipment depreciation & & & 146.47 & 3.8 & 0.02 \\
\hline $\mathrm{CSSR}^{4}$ & & & 741.00 & 5.8 & 0.02 \\
\hline TOTAL OPERATIONAL COST & & & $12,680.82$ & 100.0 & 0.42 \\
\hline
\end{tabular}

1 Interest of $3.5 \%$ p. a. over $50 \%$ of EOC during the production cycle.

${ }^{2}$ Charges over regular labor and tractor operator salaries (33\%).

${ }^{3}$ Refers to the Total Operational Cost (TOC) of the formation, distributed throughout the grapevine lifespan (20 harvests).

${ }^{4}$ Rural Social Security Contribution ( $2.3 \%$ over the gross revenue). 


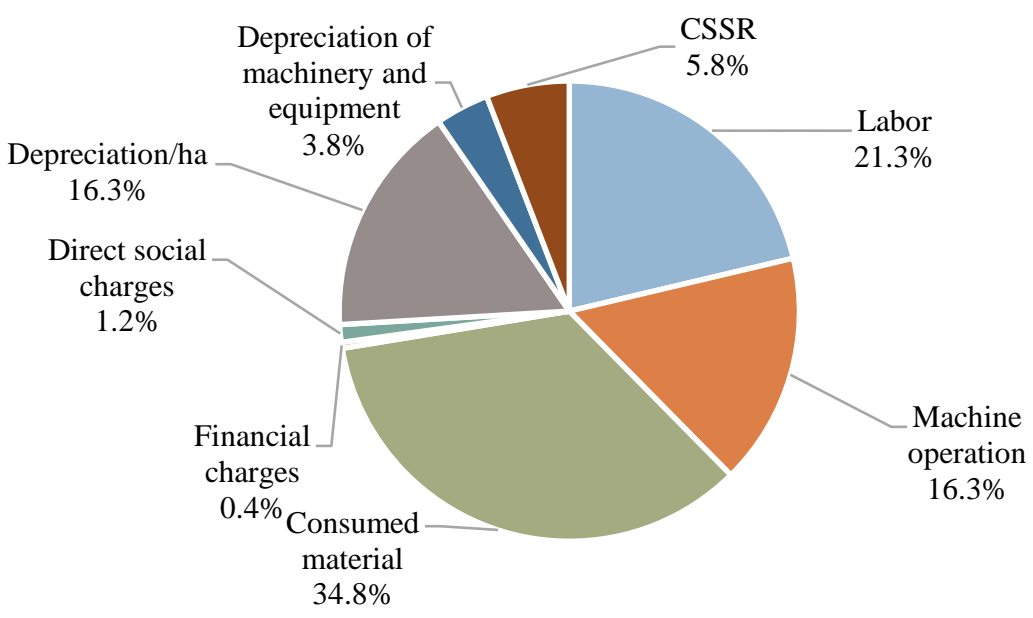

Figure 2. Percentual participation of the items forming the Total Operational Cost (TOC) in the 'Rubi' grape with abscisic acid treatment production, São Miguel Arcanjo municipality, São Paulo state, Brazil, 2016.

Table 3. Profit indicators for the 'Rubi' grapes in a pergola system with and without abscisic acid treatment, São Miguel Arcanjo municipality, São Paulo state, Brazil, 2016.

\begin{tabular}{lll}
\hline Indicator & Without treatment $^{1}$ & With treatment $^{2}$ \\
\hline Gross Revenue US\$/ha & $27,614.99$ & $32,217.49$ \\
Cash Flow US\$ & $20,571.34$ & $23,035.02$ \\
Gross Margin (EOC) \% & 292.06 & 250.86 \\
Gross Margin (TOC) \% & 174.66 & 154.06 \\
Break Even Point (EOC) kg & 7,656 & 8,582 \\
Break Even Point (TOC) kg & 10,928 & 11,851 \\
Operational Profit US\$ & $17,560.78$ & $19,536.67$ \\
Profitability Index \% & 157.25 & 164.91 \\
\hline
\end{tabular}

${ }^{1} \mathrm{~A}$ US\$ 0.92/kg sales price was considered.

${ }^{2} \mathrm{~A}$ US\$1.07/kg sales price was considered. EOC: Effective Operational Cost; TOC: Total Operational Cost

\section{Materials and methods}

\section{Location and plant materials}

Experimentation with abscisic acid (100 $\mathrm{g} \mathrm{L}^{-1}$ active ingredient, Valent BioSciences Co. ') in the 'Rubi' vine (Vitis vinifera L.) was performed during the 2015/2016 productive cycle in a commercial vineyard located in São Miguel Arcanjo municipality, São Paulo state, Brazil (23 31' S, 47은 $35^{\prime} \mathrm{W}$ and average altitude $660 \mathrm{~m}$ ). The vines were grafted on the rootstock 420-A, with the grapevines spaced at $4 \times 2 \mathrm{~m}$ and sustained in pergola system in the sixth year of production. The region's climate according to Köppen classification system is Cwa, with average annual precipitation 1,396 mm, average annual temperature $20.4{ }^{\circ} \mathrm{C}$ and relative air humidity $70.6 \%$.

Abscisic acid applications in the study region, aiming the increase of 'Rubi' grapes coloration was $400 \mathrm{mg} \mathrm{L}^{-1}$ at the beginning of the maturation $(B M)+200 \mathrm{mg} \mathrm{L}^{-1} 25$ days later with the addition of the nonionic surfactant BreakThru ${ }^{\oplus}(0.3$ $\mathrm{mL} \mathrm{L}^{-1}$ ) (Domingues Neto et al., 2017). First application occurred at BM, which was defined as softening berries and color change presenting soluble solids values of $9{ }^{\circ} \mathrm{Brix}$ and acidity of $0.9 \%$ of tartaric acid. The bunches were sprayed in the morning using a backpack sprayer with nozzles tips of hollow cone jet-JA1 set at $40 \mathrm{kgf}^{2}$ pressure and syrup volume of $900 \mathrm{~L} \mathrm{ha} \mathrm{a}^{-1}$. This setup provided full and uniform coverage of the bunches. These were the considered concentrations in the calculation of application costs in this study.

A list of the technical coefficients of the physical requirements of production factors of the grapes with and without treatment was done during the experiment.

\section{Analysis}

The economic analysis was made in two different scenarios: with and without treatment, with the objective of estimating treatment impact in both production cost and profitability, as well to evaluate the increment in the sale price of the final product due to the quality achieved with the treatment. 
The production cost and economic feasibility methodology described below and used in this study was developed by the Instituto de Economia Agrícola, a government research institute of the Secretaria de Agricultura e Abastecimento do Estado de São Paulo.

Production cost is an important tool that must be used by producers for decision-making. The production cost methodology adopted was the Operational Cost method, which is composed by all cost items (Matsunaga et al., 1976): variable (or direct costs) and fixed cost quota (or indirect).

These costs are:

Variable costs (or direct expenses): effective operational cost (EOC); represented by money expenditure, labor costs, fertilizers, defensives, fuel, and bank interest;

Non-variable costs (or indirect expenses): total operational cost (TOC). These are represented by depreciation of the assets used in the productive process, general expenses, social responsibilities (33\% over the labor expense), interest rate of $3.5 \%$ per year, rural social security contribution (RSSC, calculated $2.3 \%$ on the gross income) and depreciation of the vineyard (as a function of a one-hectare area and lifespan of 20 years).

In the study performed, information regarding the remuneration of land fixed capital, facilities and machinery were not considered, which added to EOC and TOC represent the total operational cost (TOC).

Prices, as practiced in the region where the study was performed, were collected in December, 2016 and used in the production cost calculation. The product sale price in the commercialization period was used to calculate profit indicators. Producers received US\$0.92/kg for the product without treatment and US\$1.07/kg for the product with treatment, when productivity of $30 \mathrm{t} /$ ha was considered. The values of the components of the production cost were converted from Brazilian Real (R\$) to dollar (US\$) according to Banco Central exchange rates on the day of grape's harvest (Banco Central do Brasil, 2019).

The longer lifespan consumables such as the covering plastic for berries, plastic bucket, pruning scissor, strapper and brushes were not included in the evaluation of the production cost of the 2015-2016 productive cycle.

The indicators as described by Martin et al. (1998) used in the revenue analysis were:

a) Gross Revenue (GR): it is the revenue expected due to the production per hectare according to a pre-fixed sales price, or the effectively received price.

$G R=P r^{*} P u$

where:

$P r=$ production per unit area;

$P u=$ product's unitary price.

b) Cash Flow: it is the algebraic sum of the incomes (gross revenue) and expenses (cash outflow), calculated over the activity cycle (Martin et al., 1998). The cash flow is an indicator that shows the status of the activity's cash and, when positive, it is the amount available to pay for all other fixed costs, the cover the risk and the business capacity. The cash flow is the most used indicator by rural entrepreneurs to measure the activity's results and the number of resources that will be available to pay for the other production costs.

c) Gross Margin (EOC): it is the margin in relation to the effective operational cost (EOC) or, in other words, it is the result after the producers pay the operational costs, and in relation to this same cost (in percentage); when a specific unity sales price is considered and the productivity of the production system for the activity is adopted, one has:

Gross Margin $(E O C)=((G R-E O C) / E O C) * 100$

where:

$G R$ = gross revenue;

$E O C=$ effective operational cost.

d) Gross Margin (TOC): it is calculated as the previous gross margin (EOC) but for the total operational cost (TOC). It is estimated as:

Gross Margin $(T O C)=((G R-T O C) / T O C) * 100$

where:

TOC $=$ total operational cost.

This margin indicates the availability of resources to cover all other fixed costs, the risk, and the producer's entrepreneurship capacity.

Other indicators were considered as well, such as the cost indicators per production units, which are denominated leveling points. They are defined as the minimum production necessary to pay for the cost, given a certain production cost level. The leveling points considered were:

e) Break-even point $(\mathrm{EOC})=E O C / P u$

f) Break-even point $(\mathrm{TOC})=T O C / P u$

where:

$P u=$ sales unit price.

The previous indicators allow us to visualize, for a given sales price and considering the production system productivity per activity, the cost per product unity and, when compared to productivity, how many product units are left to pay for the other costs.

g) Operational Profit (OP): it is the difference between gross revenue and total operational cost (TOC) per hectare (Martin et al., 1998). This indicator is estimated in currency units and product quantity of the activity:

$O P=G R-T O C$

The indicator of operational profit result (OP) measures the short-term profitability of the activity and diagnoses the financial and operational conditions of the agricultural activity.

h) Profitability index $(\mathrm{PI})$ : this indicator relates operational profit (OP) and gross revenue (GR), in percentage. It is an important measure of agricultural profitability, as it shows the activity tax revenue available after all operational costs, responsibilities, etc. (including depreciation) are paid:

$P I=(O P / G R) * 100$

\section{Conclusion}

The abscisic acid application is a profitable investment, which aggregates value to the final product in regions of low thermal amplitude where the grapes cannot achieve the variety characteristic coloration. In the carried out experiment, an increase of US\$ 0.15 per $\mathrm{kg}$ in the final product price when abscisic acid is applied added value to the product and increased producer's profit, presenting itself as a viable option to add value to the product in regions of low thermal amplitude.

Calculating the economic feasibility of production is an important tool for rural producers. The data here presented 
can subsidize producers' decision-making regarding the vineyard administration as the valuation attributes, mainly coloration, are requirements of the global grape market.

\section{Acknowledgments}

The authors would like to thank the producer Luiz Domingues and his family for their participation in this project and CAPES for funding and scholarship.

\section{References}

Almeida GVB (2003) A uva no contexto do mercado de frutas. Bento Gonçalves: EMBRAPA Uva e Vinho.

Banco Central do Brasil (2016). Conversor de moedas. Retrieved

from:

https://www4.bcb.gov.br/pec/conversao/conversao.asp

Cappello FP, Sposito MB, Osaki M (2017) Production costs and profitability of 'Niagara Rosada' table grape grown in different regions of São Paulo State. Revista Brasileira Fruticultura. 39(4): (e-774).

Domingues Neto FJ, Tecchio MA, Pimentel Junior A, Vedoato BTF, Lima GPP, Roberto SR (2017) Effect of ABA on color of berries and in the anthocyanin accumulation and total phenolic compounds of 'Rubi' table grape (Vitis vinifera). Aust J Crop Sci. 11(2), 199-205.

Fagundes PRS, Maia ML, Amaro AA, Oliveira MDM, Terra MM (2008) Produção e comercialização de uva Niagara nas regiões de Campinas e Jales, Estado de São Paulo. Informações Econômicas. 38(12), 61-72.
Food and Agriculture Organization of the United Nations - FAO (2019) Production crops. Retrieved from: http://www.fao.org/faostat/en/\#data

Instituto Brasileiro de Geografia e Estatística - IBGE. (2018). Levantamento sistemático da produção agrícola - LPSA. Retrieved from:

https://sidra.ibge.gov.br/pesquisa/lspa/tabelas

Inglez de Sousa, JS (Ed.) (1996) Uvas para o Brasil. Piracicaba: Fealq.

Martin NB, Serra R, Oliveira MDM, Ângelo JÁ, Okawa H (1998) Sistema integrado de custos agropecuários - CUSTAGRI. Informações Econômicas. 28(1), 7-28

Kebede T, Redae fa A (2017) Feasibility Studies on Grape Production and Business Plan Development in Axum, Ethiopia. Vegetos. 30:1.

Matsunaga M, Bemelmans PF, Toledo PEN, Dulley RD, Okawa H, Pedroso IA (1976) Metodologia de custo de produção utilizada pelo IEA. Agricultura em São Paulo. 23(1): 123-139.

Ribichaud JL, Noble AC (1990) Astringency and bitterness of selected phenolic in wines. J Science Food Agric. 53(3):343353.

Secretaria de Agricultura e Abastecimento - SAA. Coordenadoria de Desenvolvimento Rural Sustentável CDRS. Instituto de Economia Agrícola - IEA. (2019) Projeto LUPA 2016/17: censo agropecuário do Estado de São Paulo. Retrieved from: http://www.cati.sp.gov.br/projetolupa

Yin RK (2005) Estudo de caso: planejamento e métodos (3rd ed.). Porto Alegre: Bookman 